\title{
Pengembangan Instrumen Literasi Kimia pada Materi Redoks dengan Tema Silver Tarnish dan Polishing Silver
}

\section{Development of Chemical Literacy Instrument on Redox Material with Silver Tarnish and Silver Polishing Topic}

\author{
F Yuliani ${ }^{1}$, E Yusmaita $^{{ }^{*}}$ and F Gazali ${ }^{1}$ \\ 1 Pendidikan Kimia, Universitas Negeri Padang, \\ Jl. Prof. Dr. Hamka, Air Tawar Barat, Padang Utara, Sumatera Barat, Indonesia 25171 \\ *ekayusmaita@fmipa.unp.ac.id
}

\section{ARTICLE INFO}

Received on:

20 November 2020

Revised till:

17 February 2021

Accepted on:

18 February 2021

Publisher version published on:

28 February 2021

\begin{abstract}
This study aims to develop chemical literacy instrument that can be used to measure chemical literacy skills of students. The chemical literacy instrument in this study was arranged based on four domains of chemical literacy consisting of content, context, HOLS and affective aspects. This study uses the Model of Educational Reconstruction (MER) design. Content validity testing was conducted with five experts and analysed using CVR, while empirical testing of students was analysed using the Rasch model with Ministep application. Based on results of this research, chemical literacy instrument on silver tarnish and silver polishing topic is categorized as valid and reliability value is of 0,92.
\end{abstract}

\section{KEYWORDS}

Chemical Literacy Instrument, CVR, MER, Rasch Model

\section{ABSTRAK}

Penelitian ini bertujuan untuk mengembangkan instrumen literasi kimia yang dapat digunakan dalam mengukur kemampuan literasi kimia peserta didik. Instrumen literasi kimia dalam penelitian ini disusun berdasarkan empat domain yang terdiri atas aspek konten, konteks, HOLS dan sikap. Proses penyusunan instrumen dalam penelitian ini menggunakan desain Model of Educational Reconstruction (MER). Pengujian validitas konten dilakukan bersama lima orang validator dan dianalisis menggunakan CVR. Sedangkan pengujian secara empiris terhadap peserta didik dianalisis menggunakan model Rasch dengan aplikasi Ministep. Berdasarkan hasil penelitian, instrumen literasi kimia pada tema perkaratan pada perak dan pemolesan perak (silver tarnish and polishing silver) memiliki kategori valid dan memiliki nilai reliabilitas sebesar 0,92 .

KATA KUNCI

Instrumen Literasi Kimia, CVR, MER, Model Rasch 


\section{PENDAHULUAN}

Kemampuan literasi sains merupakan jalan untuk mencapai kemajuan ilmu pengetahuan dan teknologi serta ekonomi melalui pendidikan sains ${ }^{[1]}$. Adapun yang dimaksud dengan literasi sains yaitu kemampuan seseorang dalam memahami sains, mengomunikasikan sains secara lisan maupun tulisan serta mampu menerapkan kemampuan sains yang dimiliki ${ }^{2]}$. Melalui literasi sains diharapkan peserta didik dapat memahami proses sains, menerapkan pengetahuan sains secara rasional dan kreatif, serta mengambil keputusan dengan berdasarkan pertimbangan-pertimbangan sain $\mathbf{S}^{[1]}$.

Salah satu program penilaian terhadap kemampuan literasi sains secara Internasional yaitu Programme for International Student Assessment (PISA) yang diselenggarakan oleh Organization for Economic Cooperation and Development (OECD). Program ini diadakan setiap tiga tahun sekali ${ }^{[3]}$. Indonesia ikut berpartisipasi dalam program PISA semenjak tahun 2000. Berdasarkan hasil PISA pencapaian literasi sains peserta Indonesia tergolong rendah. Berdasarkan hasil PISA dua periode terakhir, Indonesia memperoleh peringkat ke 62 dari 70 Negara partisipan pada tahun $2015^{[3]}$. Sementara pada tahun 2018 Indonesia berada pada posisi ke -62 dari 71 Negara partisipan ${ }^{[2]}$. Rendahnya capaian literasi sains peserta didik Indonesia dalam studi PISA dapat disebabkan karena proses pembelajaran serta proses penilaian yang cenderung belum mendukung peserta didik dalam mengembangkan kemampuan literasi sains ${ }^{[4]}$.

Literasi kimia merupakan salah satu bagian dari literasi sains. Individu yang mempunyai kemampuan literasi kimia dapat menjelaskan peristiwa-peristiwa berdasarkan konsep kimia, memecahkan suatu permasalahan berdasarkan pemahaman kimia, serta mampu memahami dan menerapkan aplikasi kimia dalam kehidupan sehari-hari ${ }^{[5]}$. Reaksi oksidasi dan reduksi merupakan salah satu materi pelajaran kimia yang bersifat kontekstual. Peserta didik dapat memahami materi redoks dengan mengaitkannya dengan konteks yang ada dalam kehidupan seharihari, sehingga materi redoks dapat digunakan untuk melatih kemampuan literasi kimia peserta didik ${ }^{[6]}$.

Salah satu cara untuk melatih kemampuan literasi kimia peserta didik yaitu melalui instrumen literasi kimia ${ }^{[7]}$. Instrumen penilaian untuk menilai kemampuan literasi kimia sangat diperlukan untuk mengukur prestasi dalam pembelajaran kimia dibutuhkan penilaian yang bukan hanya sekadar menilai pada tingkat pemahaman serta hafalan peserta didik saja, melainkan juga mampu menilai penerapan konsep peserta didik ketika menghadapi suatu isu/permasalahan ${ }^{[8]}$.

Capaian kemampuan literasi seorang individu merupakan suatu proses yang bersifat kontinu dalam kehidupan. Instrumen literasi kimia bukanlah bertujuan untuk membedakan peserta didik apakah memiliki kemampuan literasi atau tidak ${ }^{[9]}$. Pengembangan instrumen literasi kimia memiliki tujuan supaya peserta didik melek, khususnya dalam literasi kimia ${ }^{[10]}$. Instrumen literasi kimia yang valid serta reliabel diperlukan untuk memperoleh gambaran literasi kimia peserta didik ${ }^{[11]}$. Instrumen literasi kimia yang mencakup aspek-aspek literasi kimia diharapkan dapat memberikan gambaran kemampuan literasi kimia peserta didik pada tiap levelnya ${ }^{[12]}$.

Instrumen literasi kimia pada penelitian ini disusun berdasarkan aspek literasi kimia menurut Shwartz ${ }^{[13]}$, diantaranya aspek konten, konteks, high order learning skill (HOLS) dan afektif. Adapun rubrik penilaian instrumen yaitu berdasarkan level literasi kimia yang dikemukakan oleh Bybee, yaitu scientific illiteracy, nominal scientific literacy, functional scientific literacy, conceptual scientific literacy dan multi-dimentional scientific literacy ${ }^{[13]}$. Instrumen literasi kimia pada tema silver tarnish dan polishing silver ini diharapkan dapat memberikan gambaran kemampuan literasi kimia peserta didik didik dalam materi pelajaran redoks.

\section{METODE}

Penelitian ini merupakan penelitian pengembangan dengan menggunakan desain model of educational reconstruction (MER). MER terdiri atas tiga komponen, diantaranya: klarifikasi dan analisis konten sains, penelitian mengajar dan belajar, pengembangan dan evaluasi pembelajaran ${ }^{[14]}$. Ketiga komponen dalam MER saling berhubungan dan membentuk alur yang sistematik seperti yang dijabarkan pada Gambar 1.

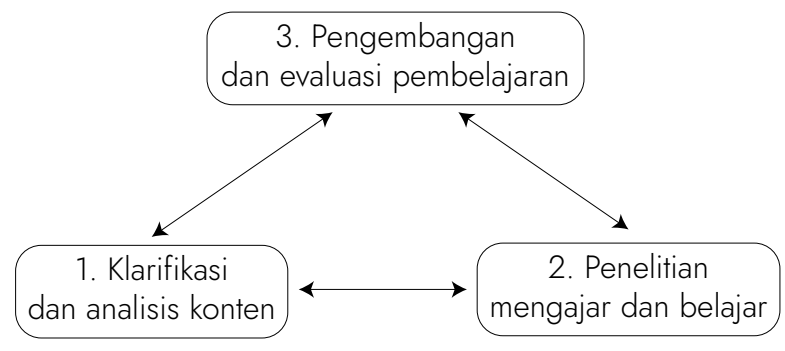

Gambar 1. Tiga komponen MER.

Dalam MER setiap tahapannya tidak mutlak harus diselesaikan terlebih dahulu, melainkan setiap tahapannya dapat dilakukan secara bolak-balik sehingga ketiga komponennya saling memengaruhi dan disesuaikan dengan tujuan penelitian yang ingin dicapai ${ }^{[9]}$.

Pelaksanaan penelitian ini dibatasi sampai pada tahapan penyelidikan empiris, yaitu pengujian validitas konten bersama subject matter expert (SME) dan tes skala kecil terhadap peserta didik. Selama proses penelitian ini ketiga komponen MER dimodifikasi menjadi skema baru, skema desain MER dalam pengembangan soal literasi kimia dijabarkan pada Gambar 2.

Validitas merupakan ukuran seberapa tepat dan cermatnya suatu alat ukur/instrumen dapat bekerja sesuai dengan fungsi ukurnya ${ }^{[15]}$. Dalam penelitian ini dilakukan pengujian validitas konten. Validitas konten yaitu kejituan suatu instrumen tes apabila ditinjau dari segi isinya ${ }^{[16]}$.Pengujian validitas konten 


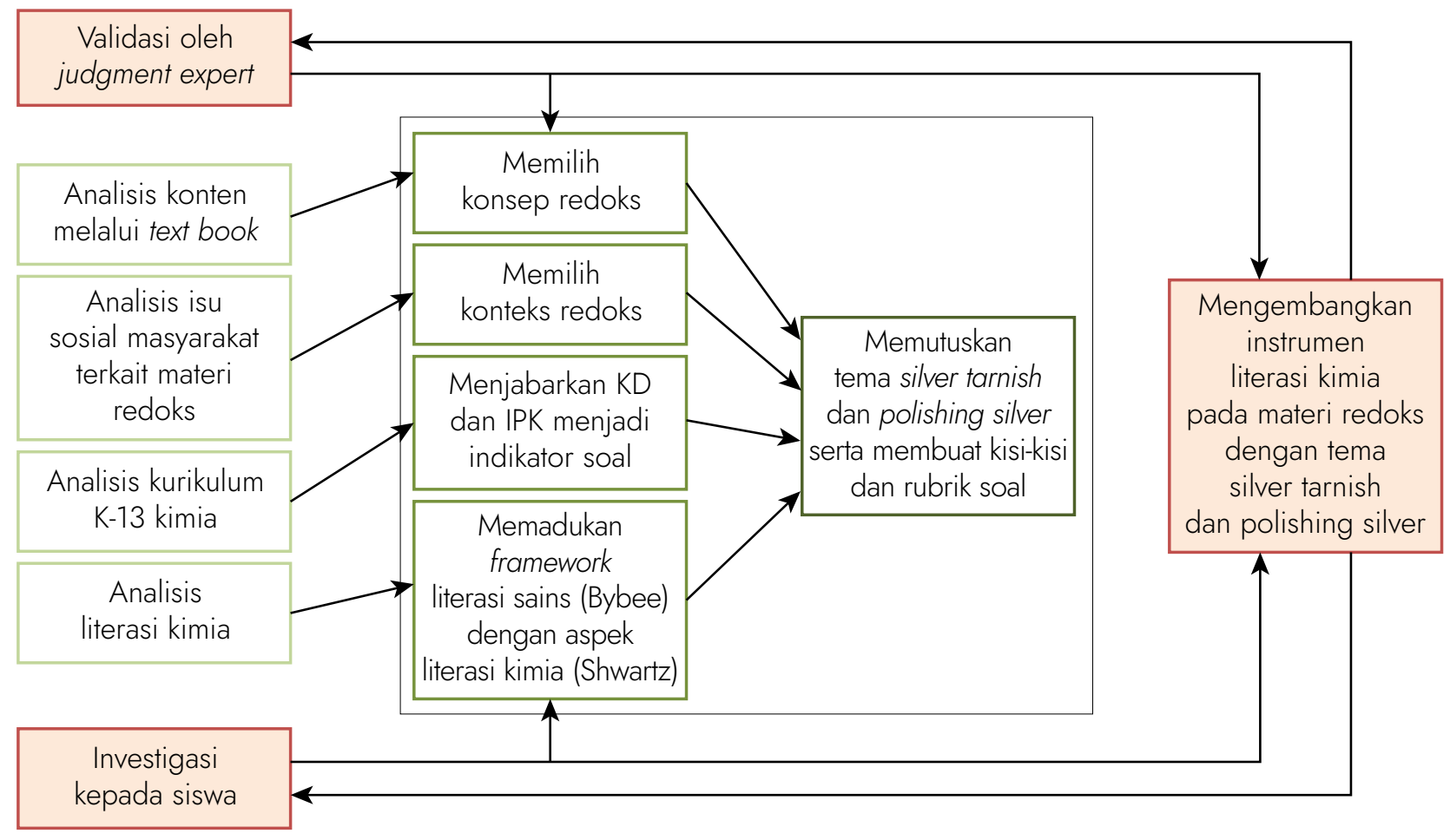

Gambar 2. Bagan MER dalam pengembangan instrumen literasi kimia.

dalam penelitian ini dianalisis menggunakan CVR yang dikembangkan oleh Lawshe (1975). Adapun rumus CVR ditunjukkan pada Persamaan 1, dimana CVR adalah content validity ratio; $\mathrm{n}_{\mathrm{e}}$ adalah jumlah validator yang menyetujui; serta $\mathrm{N}$ adalah jumlah total validator ${ }^{[17]}$.

$$
C V R=\frac{n_{e}-(N / 2)}{N / 2} \ldots \text { Persamaan } 1
$$

Pengujian secara empiris terhadap peserta didik dianalisis menggunakan model Rasch. Model Rasch merupakan suatu model pengukuran yang memanfaatkan model matematika dengan mengonversi skor mentah menjadi skor yang diproses untuk memberikan informasi yang lebih valid serta akurat $^{[18]}$. Pengukuran dengan model Rasch dapat dilakukan menggunakan aplikasi Ministep ${ }^{[19]}$.

\section{HASIL DAN DISKUSI}

\subsection{Analisis Struktur Konten}

Analisis struktur konten dilakukan atas beberapa tahapan, diantaranya analisis konten, analisis social demand, analisis kurikulum serta analisis literasi sains dan kimia yang dijabarkan pada poin-poin berikut.

\subsubsection{Analisis konten}

Analisis konten bertujuan untuk mengonfirmasi kebenaran konsep sains dan struktur konten berdasarkan sudut pandang keilmuan sains ${ }^{[10]}$. Adapun menurut Duit et al. ${ }^{[14]}$, analisis konten sains diperlukan untuk mengklarifikasi konsep sains secara spesifik serta struktur konten berdasarkan sudut pandang pendidikan. Analisis konten dilakukan terhadap materi pokok dan konsep-konsep terkait materi pelajaran kimia dengan merujuk kepada text book kimia. Adapun analisis konten dalam penelitian ini yaitu pada materi redoks untuk kelas X.

\subsubsection{Analisis social demand}

Analisis ini dilakukan terhadap isu-isu yang ada di tengah masyarakat. Analisis difokuskan pada penerapan materi pelajaran reaksi oksidasi dan reduksi dalam kehidupan sehari-hari, yaitu pada isu perkaratan pada perak serta metode yang dapat dilakukan untuk membersihkan noda pada perak. Adapun isu pada penelitian ini merujuk pada text book Brady ${ }^{[20]}$, Glencoe ${ }^{[21]}$ dan Petrucci ${ }^{[22]}$.

\subsubsection{Analisis kurikulum}

Penelitian ini menggunakan silabus kimia kurikulum 2013 revisi 2018. Analisis silabus difokuskan terkait materi redoks kelas X SMA/ MA yang terdiri atas analisis KI, KD, dan IPK yang kemudian diturunkan menjadi beberapa indikator soal yang hendak dicapai.

\subsubsection{Analisis literasi sains dan kimia}

Dalam tahapan ini dilakukan analisis kerangka literasi sains menurut Bybee ${ }^{[13]}$ serta aspek literasi kimia menurut Shwartz ${ }^{[13]}$ yang disesuaikan dengan materi redoks dan isu yang telah dianalisis pada tahapan sebelumnya. Hasil dari analisis ini kemudian dirancang menjadi kisi-kisi soal serta kartu soal. Adapun komponen kisi-kisi soal literasi kimia terdiri atas kompetensi dasar, indikator pencapaian kompetensi, indikator soal, level pengetahuan dan level kognitif, aspek literasi kimia, nomor soal dan jenis soal. Adapun jenis soal yang dikembangkan dalam penelitian ini yaitu soal esai. Sementara muatan kartu soal terdiri atas wacana, 
pertanyaan dan rubrik penilaian soal berdasarkan level literasi kimia.

\subsection{Studi Empiris}

\subsubsection{Validasi bersama judgment experts}

Pengujian validitas konten dilakukan bersama lima orang validator yang terdiri atas dua orang dosen jurusan kimia FMIPA Universitas Negeri Padang serta tiga orang guru kimia SMA. Adapun instrumen penilaian validitas konten soal literasi kimia ini terdiri atas 13 aspek yang mencakup aspek materi, aspek bahasa, aspek konstruksi, serta aspek grafis. Hasil dari penilaian validitas konten akan dijadikan sebagai dasar untuk memperbaiki butir item instrumen yang masih kurang baik. Kualitas instrumen yang valid selanjutnya digunakan untuk mengukur kemampuan peserta didik. Hasil validitas konten dianalisis menggunakan CVR. Adapun hasil perhitungan CVR yang diperoleh dapat dilihat pada Tabel 1.

Tabel 1. Hasil Validitas Konten.

\begin{tabular}{c|c|c|c|c}
\multirow{2}{*}{$\begin{array}{c}\text { Aspek } \\
\text { Penilaian }\end{array}$} & \multicolumn{4}{|c}{ Butir Soal } \\
\cline { 2 - 5 } & \multicolumn{2}{|c}{$\mathbf{1}$} & \multicolumn{2}{|c}{2} \\
\cline { 2 - 5 } & ne & CVR & ne & CVR \\
\hline 1 & 5 & 1 & 4 & 0.6 \\
\hline 2 & 5 & 1 & 4 & 0.6 \\
\hline 3 & 5 & 1 & 5 & 1 \\
\hline 4 & 5 & 1 & 4 & 0.6 \\
\hline 5 & 5 & 1 & 4 & 0.6 \\
\hline 6 & 5 & 1 & 5 & 1 \\
\hline 7 & 5 & 1 & 5 & 1 \\
\hline 8 & 5 & 1 & 5 & 1 \\
\hline 9 & 5 & 1 & 5 & 1 \\
\hline 10 & 5 & 1 & 5 & 1 \\
\hline 11 & 5 & 1 & 5 & 1 \\
\hline 12 & 5 & 1 & 5 & 1 \\
\hline 13 & 5 & 1 & 5 & 1
\end{tabular}

Untuk menentukan valid atau tidaknya suatu butir soal digunakan teori CVR menurut Wilson ${ }^{[23]}$ yang merupakan penjabaran dari konsep Lawshe. Nilai kritis CVR untuk lima orang validator yaitu 0,57 $(p=0,2)$. Hal ini bermakna bahwa suatu item akan bernilai valid atau esensial apabila memiliki nilai CVR yang lebih besar dari nilai kritis. Berdasarkan Tabel 1, nilai CVR yang diperoleh pada soal pertama yaitu 1 , sementara nilai CVR soal kedua yaitu 0,6 dan 1. Hal ini menunjukkan bawah soal berada dalam kategori valid.

\subsubsection{Studi empiris terhadap siswa}

Pengujian instrumen literasi kimia secara terbatas dilakukan terhadap 30 orang siswa SMA yang telah mempelajari materi pelajaran reaksi oksidasi dan reduksi. Hasil tes yang diperoleh kemudian dianalisis menggunakan aplikasi Ministep untuk memperoleh nilai validitas dan reliabilitas secara empiris. Adapun hasil analisis yang diperoleh dijabarkan pada Tabel 2.

Tabel 2. Analisis instrumen dengan model Rasch.

\begin{tabular}{c|c|c|c|c}
\multicolumn{2}{c|}{ INFIT } & \multicolumn{2}{c|}{ OUTFIT } & \multirow{2}{*}{$\begin{array}{c}\text { Relia- } \\
\text { bilitas }\end{array}$} \\
\hline MNSQ & ZSTD & MNSQ & ZSTD & \\
\hline 0,95 & $-0,05$ & 0,97 & 0,07 & 0,92
\end{tabular}

Instrumen soal yang valid berdasarkan model Rasch yaitu dilihat berdasarkan nilai infit dan outfit yang terdiri atas MNSQ serta ZSTD. Adapun rentang nilai MNSQ yang diperbolehkan yaitu 0,5 hingga 1,5 sementara nilai ZSTD yaitu -2 hingga $+2^{[19]}$. Berdasarkan hasil analisis dengan model Rasch yang disajikan pada Tabel 2, nilai MNSQ dan ZSTD yang diperoleh berada dalam rentang yang diperbolehkan, hal ini bermakna bahwa instrumen bernilai valid secara empiris. Sementara nilai reliabilitas soal yang diperoleh yaitu 0,92 . Nilai reliabilitas soal dalam rentang 0,91 sampai dengan 0,94 memiliki kategori sangat bagus ${ }^{[24]}$. Hal ini menunjukkan bahwa instrumen literasi kimia valid dan reliabel dan dapat digunakan untuk mengukur kemampuan literasi kimia peserta didik pada materi redoks khususnya pada tema silver tarnish dan polishing silver.

\subsection{Konstruksi Soal}

Instrumen literasi kimia yang dikembangkan berdasarkan desain MER pada penelitian ini dijabarkan pada Tabel 3.

\section{SIMPULAN}

Berdasarkan penelitian yang telah dilakukan, instrumen literasi kimia pada tema silver tarnish dan polishing silver memiliki kategori valid dari segi konten serta valid dan reliabel berdasarkan pengujian empiris, adapun nilai reliabilitas yang diperoleh yaitu 0,92.

Tabel 3. Rancangan Soal Literasi Kimia.

\section{Tema: Silver Tarnish \& Polishing Silver}

\section{Silver Tarnish}

Silver tarnish atau noda pada perak dapat menyebabkan perak menjadi kusam dan tampilannya menjadi kurang menarik. Noda pada perak terbentuk akibat reaksi antara perak dengan hidrogen sulfida di udara sehingga menghasilkan perak sulfida yang berwarna kehitaman. Adapun reaksi pembentukan perak sulfida adalah:

$$
\mathrm{O}_{2}(g)+4 \mathrm{Ag}(\mathrm{s})+2 \mathrm{H}_{2} \mathrm{~S}(\mathrm{~g}) \rightarrow 2 \mathrm{Ag}_{2} \mathrm{~S}(\mathrm{~s})+2 \mathrm{H}_{2} \mathrm{O}(\mathrm{l}) \ldots \text { Reaksi } 1
$$


Tabel 3. Rancangan Soal Literasi Kimia (sambungan).

\section{Tema: Silver Tarnish \& Polishing Silver}

\section{Polishing Silver}

Banyak pemoles perak komersial mengandung abrasive yang dapat membantu menghilangkan noda, tetapi metode tersebut juga dapat mengikis permukaan perak. Cara yang lebih efektif untuk menghilangkan noda dari permukaan benda perak yaitu menggunakan aluminium foil dengan cara seperti berikut:

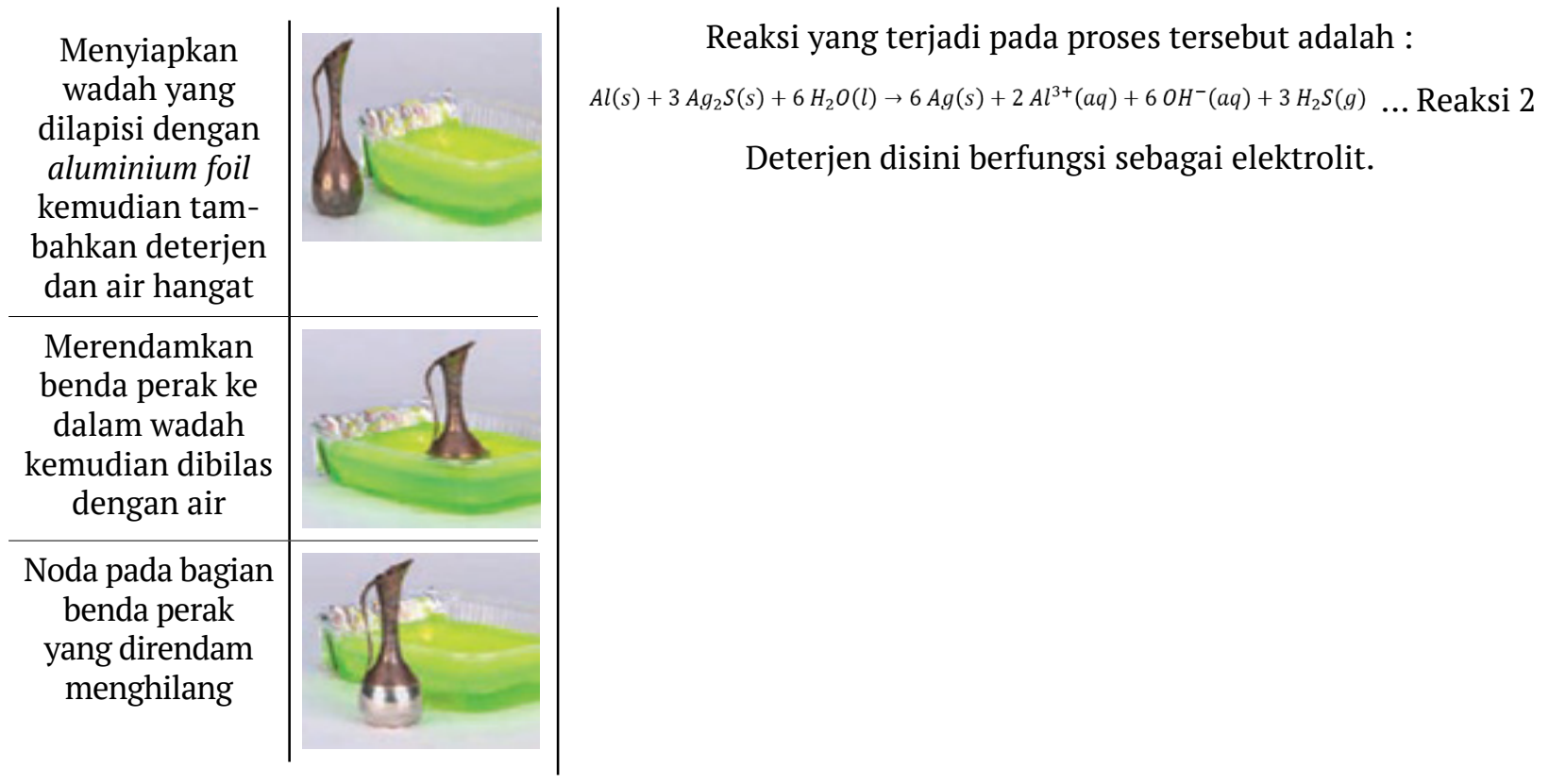

\section{Soal}

1. Jelaskan perbedaan reaksi yang terjadi pada perak berdasarkan konsep bilangan oksidasi dalam peristiwa silver tarnish dan proses polishing silver!

2. Jika anda memiliki benda yang terbuat dari perak, apakah anda akan menggunakan Aluminium foil untuk menghilangkan noda pada benda perak tersebut? mengapa demikian?

Tabel 4. Rubrik penilaian soal 1.

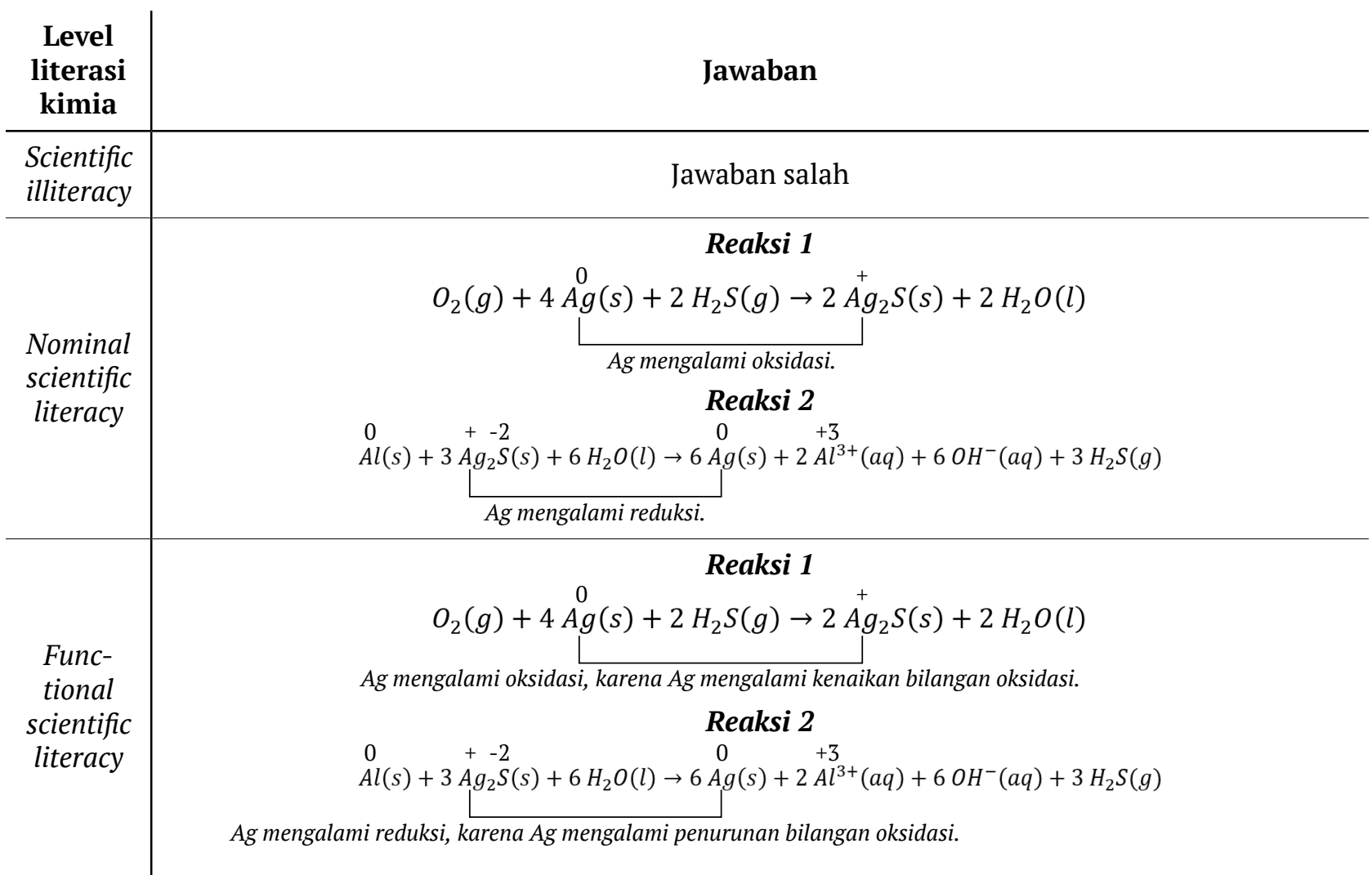


Tabel 4. Rubrik penilaian soal 1 (sambungan).

\begin{tabular}{|c|c|}
\hline $\begin{array}{l}\text { Level } \\
\text { literasi } \\
\text { kimia }\end{array}$ & Jawaban \\
\hline \multirow{5}{*}{$\begin{array}{c}\text { Con- } \\
\text { ceptual } \\
\text { Scientific } \\
\text { Literacy }\end{array}$} & 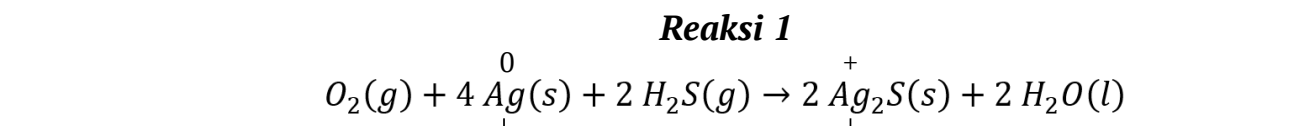 \\
\hline & $\begin{array}{l}\text { Ag mengalami oksidasi, reaksi oksidasi adalah reaksi dimana suatu zat mengalami } \\
\text { kenaikan bilangan oksidasi, dilihat dari unsur Ag mengalami kenaikan bilangan oksidasi dari } 0 \text { menjadi }+1 \text {. }\end{array}$ \\
\hline & Reaksi 2 \\
\hline & 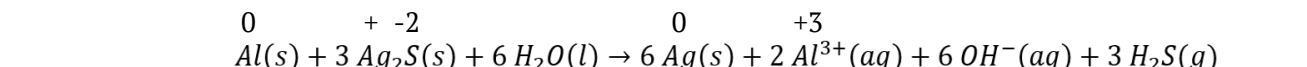 \\
\hline & $\begin{array}{l}\text { Ag mengalami reduksi, reaksi reduksi adalah reaksi dimana suatu zat mengalami } \\
\text { penurunan bilangan oksidasi, dilihat dari unsur Ag mengalami penurunan bilangan oksidasi dari }+1 \text { ke } 0 \text {. }\end{array}$ \\
\hline
\end{tabular}

Tabel 5. Rubrik penilaian Soal 2.

\begin{tabular}{l|l}
\multicolumn{1}{c|}{$\begin{array}{c}\text { Level } \\
\text { literasi kimia }\end{array}$} & \multicolumn{1}{c}{ Jawaban } \\
\hline Scientific illiteracy & Tidak ada jawaban \\
\hline $\begin{array}{l}\text { Nominal scientific } \\
\text { literacy }\end{array}$ & Ya/Tidak \\
\hline $\begin{array}{l}\text { Functional } \\
\text { scientific literacy }\end{array}$ & $\begin{array}{l}\text { Ya, karena dengan } \\
\text { menggunakan dengan } \\
\text { menggunakan aluminium foil } \\
\text { tidak mengurangi kandungan } \\
\text { pada benda perak dan } \\
\text { prosedurnya mudah sehingga } \\
\text { dapat dilakukan }\end{array}$ \\
\hline
\end{tabular}

\begin{tabular}{l|l}
\multicolumn{1}{c|}{$\begin{array}{c}\text { Level } \\
\text { literasi kimia }\end{array}$} & \multicolumn{1}{|c}{ Jawaban } \\
\hline Conceptual & $\begin{array}{l}\text { Ya, noda pada perak } \\
\text { disebabkan karena adanya } \\
\text { reaksi antara perak } \\
\text { dengan ion sulfida, dengan } \\
\text { metode pemolesan perak } \\
\text { menggunakan aluminium foil } \\
\text { akan terjadi reaksi redoks } \\
\text { antara aluminium foil dengan } \\
\text { noda pada perak }\left(\mathrm{Ag}_{2} \mathrm{~S}\right) \\
\text { yang mengakibatkan ion } \\
\text { sulfida terlepas dari perak } \\
\text { sehingga benda perak akan } \\
\text { bersih seperti semula, dan } \\
\text { dengan metode ini tidak } \\
\text { menyebabkan terjadinya } \\
\text { pengikisan pada permukaan } \\
\text { benda perak }\end{array}$ \\
\hline
\end{tabular}

\section{REFERENSI}

1. Thummathong R, Thathong K. Construction of a Chemical Literacy Test for Engineering Students. Turkish Sci Educ. 2016;13(3):18598.

2. Narut YF, Supardi K. Literasi Sains Peserta Didik dalam Pembelajaran IPA di Indonesia. Inov Pendidik Dasar. 2019;3(1):61-9.

3. Pratiwi SN, Cari, Aminah NS. Pembelajaran IPA Abad 21 dengan Literasi Sains Siswa. J Mater dan Pembelajaran Fis. 2019;9(1):34-42.

4. Yuliati Y. Literasi Sains dalam Pembelajaran IPA. Jurnal Cakrawala Pendas. 2017;3(2):21-8.

5. Fahmina SS, Indriyanti NY, Setyowati WAE, Masykuri M, Yamtinah S. Dimension of Chemical Literacy and its Influence in Chemistry Learning. J Phys Conf Ser. 2019;1233 (2019.

6. Riyadhin AIF, Mitarlis. Pengembangan Lembar Kegiatan Siswa (LKS) untuk Melatihkan Kemampuan Literasi Sains Siswa pada Materi Redoks. UNESA J Chem Educ. 2018;1(1):8-13.

7. Prastiwi MNB, Rahmah N, Khayati N, Utami DP, Primastuti M, Majid AN. Studi Kemampuan Literasi Kimia Peserta Didik pada Materi Elektrokimia. In: Sinergi Penelitian dan Pembelajaran untuk Mendukung Pengembangan Literasi Kimia pada Era Global. 2017. p. 101-8.

8. Sumarni W, Prasida HW, Sumarti SS. Pengembangan Instrumen Penilaian Kemampuan Kognitif dan Afektif Berbasis Literasi Sains pada Materi Larutan Penyangga. IN: Seminar Universitas PGRI Semarang, Seminar Nasional Alfa VII. 2017;457-67.

9. Yusmaita E, Nasra E. Perancangan Assesmen Literasi Kimia dengan Menggunakan Model of Educational Reconstruction ( MER ) pada Tema Air. 2017;1(2).

10. Wahyuni A, Yusmaita E. Perancangan Instrumen Tes Literasi Kimia Pada Materi Asam dan Basa. Edukimia. 2020;2(3).

11. Pakesa CM, Yusmaita E. Perancangan Assesmen Literasi Kimia Pada Materi 
Laju Reaksi Kelas XI SMA/MA. Edukimia. 2019;1(4):84-9.

12. Afifah S, Yusmaita E. Perancangan Assesmen Literasi Kimia Pada Materi Termokimia Kelas XI SMA/MA. Edukimia. 2019;1(4):79-83.

13. Shwartz Y, Ben-zvi R, Hofstein A. The Use of Scientific Literacy Taxonomy for Assessing The Development of Chemical Literacy Among High-School Students. Chem Educ Res Pract. 2006;7(4):203-25.

14. Duit R, Gropengießer H, Kattmann U, Komorek M, Parchmann I. The Model of Educational Reconstruction - A Framework for Improving Teaching and Learning Science 1. Kiel: 2012;13-37.

15. Supardi. Penilaian Autentik Pembelajaran Afektif, Kognitif dan Psikomotor. Jakarta: Rajawali Pers; 2016.

16. Latisma DJ. Evaluasi Pendidikan. Padang: UNP Press; 2011.

17. Hendryadi. Validitas Isi : Tahap Awal Pengembangan Kuesioner. Jurnal Riset Manajemen dan Bisnis (JRMB) Fakultas Ekonomi UNIAT. 2017;2(2):169-78.

18. Fahmina SS, Masykuri M, Ramadhani DG, Yamtinah S. Content validity uses Rasch model on computerized testlet instrument to measure chemical literacy capabilities Content Validity Uses Rasch Model on Computerized Testlet Instrument to Measure Chemical Literacy Capabilities. AIP Conf Proc 2194. 2019;020023(December).

19. Rusilowati A. Asesmen Literasi Sains : Analisis Karakteristik Instrumen dan Kemampuan Siswa Menggunakan Teori Tes Modern Rasch Model. In: Prosiding Seminar Nasional Fisika Universitas Riau ke-3 2018. 2018.

20. Brady JE, Jespersen ND, Hylsop A. Chemistry: The Molecular Nature of Matter. 6th Edition. USA: John Wiley \& Sons; 2012.

21. Glencoe. Chemistry: Concepts and Applications. United States of Amerika: McGraw-Hill; 2002.

22. Petrucci, RH, Herring FG, Madura JD, Bissonnette C. General Chemistry: Principles and Modern Applications. 10th Edition. Toronto: Pearson Education; 2011.

23. Wilson FR, Pan W, Schumsky DA. Measurement and Evaluation in Counseling and Development Recalculation of the Critical Values for Lawshe' s Content. SAGE Journals. 2012;197-210.

24. Sumintono B, Widhiarso W. Aplikasi Model Rasch untuk Penelitian Ilmu-Ilmu Sosial. Edisi Revisi. Jakarta: Rajawali Pers; 2014. 